\title{
EL EJERCICIO DE LA LIBERTAD EMPRESARIAL EN EL ORDENAMIENTO JURÍDICO ESPAÑOL
}

\section{THE EXERCISE OF THE ENTREPRENEURIAL FREEDOM RIGHT INTO SPANISH LEGAL SYSTEM}

\author{
NOEMÍ JIMÉNEZ CARDONA ${ }^{1}$
}

\section{RESUMEN}

El presente artículo tiene por objeto el estudio del complejo ejercicio del derecho a la libertad empresarial de los operadores económicos de carácter privado en el ordenamiento jurídico español. En concreto, centra su análisis en el marco constitucional que establece las directrices y principios fundamentales que debe regir toda actuación empresarial dentro del espacio económico. Tras examinar las principales características que derivan de nuestro sistema de organización económica (economía de mercado, libre competencia y libertad empresarial) se procede, a continuación, a perfilar la naturaleza jurídica y el alcance, desde una perspectiva objetiva y subjetiva, del derecho a la libertad de empresa. En último lugar, se analizan los pronunciamientos más destacados que hasta la fecha han emitido los órganos jurisdiccionales españoles en orden a las limitaciones e interdicciones que los operadores económicos deben tolerar, por no afectar al contenido esencial de este derecho económico-constitucional, dentro de su esfera empresarial

PALABRAS CLAVE: Derecho a la libertad de empresa - Economía de mercado - Libre competencia - Organización empresarial - Modelos económicos

\begin{abstract}
The purpose of this article is to study the elaborate exercise of the entrepreneurial freedom right of private economic operators provided into Spanish legal system. It focuses on the constitutional framework that establishes the fundamental guidelines and principles that should govern all business action within the economic area. After examining the main characteristics deriving from our system of economic organization (market economy, free competition and entrepreneurial freedom), it analyses the legal nature and scope, from an objective and subjective perspective, of the entrepreneurial freedom right. Last, it analyses the most important decisions issued to date by the Spanish courts on the limitations and interdictions that economic operators must tolerate within their business sphere because they do not affect the essential content of this economic-constitutional right.
\end{abstract}

KEYWORDS: Entrepreneurial freedom right - Market economy - Free competition - Business organization - Economic models

\footnotetext{
${ }^{1}$ Doctora en Derecho Mercantil e Investigadora Postdoctoral del Departamento de Derecho Privado (Área de Derecho Mercantil) de la Universitat de Barcelona, España. Afiliação: Universitat de Barcelona, Espanha. ORCID:https://orcid.org/0000-0003-3197-4775. E-mail: njimenezcardona@ub.edu
} 


\section{LA CONFIGURACIÓN DE LA ACTUACIÓN EMPRESARIAL EN EL ACTUAL MODELO ECONÓMICO-ORGANIZATIVO ESPAÑOL}

\section{I.1. CONCEPTO Y RELEVANCIA CONSTITUCIONAL DE NUESTRO MODELO ECONÓMICO-CONSTITUCIONAL: ECONOMÍA DE MERCADO Y LIBERTAD DE EMPRESA}

Cualquier comunidad social mínimamente organizada debe estar provista de todo un conjunto de mecanismos, conocidos como "sistemas de organización económica", con los que poder satisfacer las necesidades más primarias de suministro y adquisición de la sociedad. Dichos sistemas de organización permiten, en mayor o menor medida, dar respuesta, a toda una serie de necesidades. En primer lugar, y en atención al acceso y disponibilidad de los recursos de los que se pueda hacer uso en la comunidad, todo modelo organizativo debe identificar y priorizar los bienes que definitivamente acabarán produciéndose (de acuerdo con las necesidades que se consideran más prevalentes y, por lo tanto, se pretendan satisfacer en primer término). En segundo lugar, una vez identificados los productos o servicios que van a ponerse a disposición en el mercado, debe ofrecerse una respuesta en torno a cómo se va a organizar la producción de tales bienes (es decir, qué insumos o materias primas van a resultar necesarias en el proceso de transformación) y mediante qué procesos o transformaciones van a someterse en la cadena de producción (VÁZQUEZ ALBERT, 2018, p.109). En último lugar, será igualmente necesario identificar el grupo de individuos a los que va a ir dirigido el producto en cuestión (determinación del público objetivo), así como establecer aquellas vías de distribución que resulten más eficaces en orden a conseguir que el mayor número de demandantes pueda acceder a la adquisición del producto o servicio (SAMUELSON y NORDHAUS, 1991, p. 28).

Esta necesidad fundamental, inherente a toda formación política organizada, y a cuyo propósito atienden los diferentes sistemas de organización económica, es debidamente abordada, como no podía ser de otro modo, en nuestro ordenamiento jurídico. En consonancia con el modelo de Estado democrático, social y de Derecho proclamado en el art. 2 de la Constitución Española de 1978 (en adelante, CE), nuestra Carta Magna contiene toda una serie de preceptos que, si bien aparecen disgregados a lo largo de su articulado -lo que requiere mantener una visión transversal y conjunta de todos ellos-, son los encargados de delimitar el marco jurídico fundamental sobre el que se asienta la estructura y funcionamiento de la actividad económica de nuestro sistema político.

El núcleo fundamental de nuestro modelo económico aparece regulado en el art. 38 CE. Dicho precepto dispone que "Se reconoce la libertad de empresa en el marco de la economía de 
mercado. Los poderes públicos garantizan y protegen el ejercicio y la defensa de la productividad, de acuerdo con las exigencias de la economía general y, en su caso, de la planificación". Tras la lectura de dicho artículo es posible inferir que éste, en términos generales, aparece como una norma completa, si bien insuficientemente descriptiva. A diferencia de lo que sucede con otros ámbitos de la vida político-social consagrados a nivel constitucional, nuestra Norma Fundamental ha optado por instaurar, sin fisura alguna, la economía de mercado como modelo rector de nuestro sistema económico, pero para ello ha empleado, como indica Cazorla Prieto (1980, p. 468) una cláusula de "difícil catalogación jurídica".

Que nuestro legislador constituyente no optase, en este punto, por emplear términos concretos, definidos y tasados, ha comportado un problema añadido en la labor del legislador ordinario, ya que éste no solo no puede disponer de los elementos principales que conforman nuestro modelo económico (sin perjuicio de que puedan ser objeto de un mayor desarrollo legal siempre que se respete el núcleo esencial de los mismos); sino que, además, también resulta obligatorio efectuar, con carácter previo, una operación de delimitación conceptual. Así acontece, precisamente, respecto a la economía de mercado, pues bajo esta expresión puede tener cabida tanto un sistema de libre mercado puro y liberal, así como otros modelos de corte socialista y con un mayor grado de intervención pública (GOIG MARTÍNEZ, 1996, pp. 731-732)². En cualquier caso, resulta factible concluir que la libertad de empresa, por su expresa mención en el propio cuerpo del precepto, también desempeñará un papel fundamental y merecedor del mismo grado de protección y blindaje constitucional.

Todo parece apuntar a que nuestra Constitución hace uso de un sentido funcional de la economía de mercado sin necesitar, por lo tanto, de ninguna otra especificación (MENÉNDEZ MENÉNDEZ, 1982, p. 42). De acuerdo con una lectura armónica con el resto de preceptos de la norma constitucional de referencia, se puede deducir que la expresión recogida bajos los términos “economía de mercado" resguarda un sistema de libre mercado donde la actividad económica queda encomendada, como preferencia principal, a la iniciativa privada (y así se manifiesta con el reconocimiento expreso de la libertad de empresa) (FONT GALÁN, 1987, p. 30-34). Sin embargo, de tal razonamiento no puede desprenderse que en dicho texto normativo se esté impidiendo la dirección y corrección de este sistema por parte de los poderes públicos. Si nuestra Constitución huye de redacciones extremas, a favor de la conciliación política, con mayor razón lo hará de aplicaciones sesgadas. Por consiguiente, la iniciativa privada no debe entenderse en un sentido puro y excluyente, sino que, por el contrario, el sistema consagrado a nivel constitucional necesita ser

\footnotetext{
${ }^{2}$ La pluralidad de interpretaciones en torno al contenido y límites de nuestro modelo de "economía de mercado" pueden consultarse en: JIMÉNEZ CARDONA, Noemí. La dimensión constitucional del Derecho de la Competencia. Curitiba: Juruá Editora, 2021, págs. 43-72; MENÉNDEZ MENÉNDEZ, Aurelio. Constitución, sistema económico y Derecho mercantil. Madrid: Cantoblanco, 1982, págs. 30-34.
} 
congeniado con la aplicación de otras políticas públicas encargadas de proteger distintos intereses, también de relevancia social para la comunidad (VICIANO PASTOR, 2014, p. 604-606).

Ahora bien, el art. $38 \mathrm{CE}$ no puede someterse a una lectura única. El propio precepto contiene, como anteriormente se indicaba, dos instituciones que, pese a estar en estrecha conexión, se manifiestan en eslabones distintos de nuestra estructura económica: la economía de mercado, como principio general que debe regir la ordenación económica (principio rector de naturaleza público-económica que constituye el marco general de toda la actividad económica); y la libertad de empresa, como uno de los elementos imprescindibles e individualizados que debe irradiar todo el modelo organizativo-económico sobre el que se asienta nuestro sistema (derecho subjetivo reconocido constitucionalmente) (JIMÉNEZ CARDONA, 2021, p. 45-46).

Nuestro texto constitucional ha consagrado el sistema de libre mercado (rectius, "economía de mercado") como principio organizativo de naturaleza pública que debe presidir toda nuestra ordenación económica. A diferencia de los sistemas económicos centralizados, el modelo de economía de mercado o de libre mercado se caracteriza por encomendar la tarea de satisfacer las necesidades de la población, no ya a una entidad de carácter supraindividual (como correspondería al propio Estado), sino, antes al contrario, a los propios integrantes que conforman e intervienen en la sociedad ${ }^{3}$.

En este sentido, las tareas de producción de bienes y servicios, así como de gestión y acceso a los recursos, se confieren a la plena actuación privada. Con ello, el modelo de libre mercado se caracteriza por ser un modelo de concepción abierta y descentralizada (FIKENTSCHER, 1984, p. 463 ) en el que se instaura el intercambio, voluntario y con ánimo lucrativo, de bienes y servicios entre operadores económicos e individuos demandantes (consumidores o usuarios) (HERNÁNDEZ DELGADO, 1999, p. 239-240), y cuyo comportamiento empresarial quedará determinado, de una parte, por la libertad de empresa y, de otra, por el poder de decisión de compra de los demandantes (WAELBROECK y FRIGNANI, 1998, p. 330-331).

\section{I.2. LA LIBERTAD DE EMPRESA Y SU ANCLAJE CONSTITUCIONAL: LA INTERVENCIÓN DE LOS OPERADORES ECONÓMICOS}

Sin ánimo de adentrarnos, con detalle, en las complejidades que todo estudio acerca de la teoría económica requiere, puede afirmarse que el sistema de libre mercado es el modelo que confiere un mayor grado de libertad económica, ya que la determinación de aquello que debe

\footnotetext{
${ }^{3}$ Para un mayor análisis acerca de la conceptualización de los diferentes sistemas económicos y sus rasgos característicos, con especial referencia al continente europeo, véase, por todos: BARRE, Raymond. Economía política, 5ª ed. Barcelona: Ariel, 1967, 1v., págs. 156-168.
} 
producirse, así como los procesos a seguir y la cuota de producción, quedarán concretados, en su mayor parte, por la plena voluntad de los operadores económicos. Ahora bien, el funcionamiento ordinario de este sistema, regido íntegramente por la libre decisión y criterio de los agentes intervinientes, se desarrolla en una continua paradoja: es el propio sistema de libre mercado el que, junto a conceder la plena libertad de actuación, acaba por condicionar e inducir las conductas de los sujetos que en él intervienen (BARRE, 1967, p. 465-470).

Por más que los operadores económicos puedan actuar con total libertad de criterio, su comportamiento siempre responderá a un mismo paradigma que se encuentra íntimamente relacionado con el funcionamiento cíclico del mercado. Así pues, los operadores económicos, motivados por la obtención de rendimiento económico en su actividad, dirigirán su producción de acuerdo con las preferencias reveladas por los consumidores (AREEDA, 1984, p. 45-46; SPULBER, 2013, p. 129-135) y, asimismo, evitarán, debido a su coste, el uso infructuoso de recursos (ORTIZ BLANCO, 2008, p. 33). De esta forma, el sistema de libre mercado se autocompleta por sí mismo de forma equitativa, porque si bien es cierto que, en un principio, son los operadores económicos privados los que se encargan de dirigir los procesos productivos, la gestión de los recursos y su puesta a disposición en el mercado (FIKENTSCHER, 1984, p. 475); no lo es menos que, en un segundo plano, participan todos los sujetos implicados en la toma de decisiones, ya que los operadores actuarán en prosecución de los intereses que los consumidores muestren (HERRERO SUÁREZ, 2006, p. 46-48). De ahí, precisamente, que el comportamiento y las preferencias de los consumidores actúen como elementos directores de la actividad productiva a fin de asegurarse los agentes económicos el mayor éxito y acogida posible en el mercado, así como la obtención de un mayor rendimiento económico (SAMUELSON y NORDHAUS, 1991, p. $81-82)$

No obstante, es necesario precisar que aun cuando nuestro modelo de libre mercado encomiende las labores de producción y distribución a los distintos operadores privados, lo cierto es que no les reserva la actividad empresarial de forma excluyente y exclusiva, sino que ésta debe resultar compatible con una posible participación pública. En este sentido, así se prevé en el art. $128 \mathrm{CE}$ al disponer en su apartado segundo que: "Se reconoce la iniciativa pública en la actividad económica. Mediante ley se podrá reservar al sector público recursos o servicios esenciales, especialmente en caso de monopolio, y asimismo acordar la intervención de empresas cuando así lo exigiere el interés general".

De una lectura conjunta de los arts. 38 y $128.2 \mathrm{CE}$, dos son las puntualizaciones que deben inferirse. La primera de ellas se corresponde con la posibilidad de intervención de la Administración 
en el sistema de libre mercado ${ }^{4}$, intervención ésta que, en todo caso, deberá hacerse respetando y generando competencia (MARCOS FERNÁNDEZ, 2018, p. 10-18). El art. 128.2 CE expresamente menciona que "se reconoce la iniciativa pública en la actividad económica". Por consiguiente, el modelo de libre mercado no debe visualizarse únicamente como un espacio de intervención de operadores económicos particulares, sino que en él también hay lugar para la actividad de la Administración, ya sea como un prestador más en un sector ya consolidado, o como impulsor de un sector de mercado todavía en vías de desarrollo (en este último caso, la Administración actuaría, además, como promotora de la competencia en el mercado).

Es más, la reserva de la actividad empresarial al ámbito privado no hace de por sí incompatible la prestación de las mismas funciones por operadores públicos, ya que éstos quedan igualmente sujetos a la pugna concurrencial que tiene lugar en el espacio de intercambio. De este modo, se reconoce, en sede constitucional, una facultad de intervención a favor de la Administración Pública en régimen de plena concurrencia con la actividad ofertada por los operadores económicos privados (PAZ-ARES RODRÍGUEZ y ALFARO ÁGUILA-REAL, 2008, p. 989) ${ }^{5}$. Intervención pública que podrá materializarse bien a través de entes públicos o bien mediante la constitución ad hoc de organismos con personalidad jurídica propia regidos por el Derecho Privado (GALÁN CORONA, 1975, p. 327-336).

Ahora bien, el inconveniente que puede resultar más acuciante en un terreno fundamentado en la iniciativa privada pero que, paralelamente, permite la entrada a la iniciativa pública, es que ésta última no acabe por ser la iniciativa predominante ${ }^{6}$. En todo caso, debe afirmarse que la

\footnotetext{
${ }^{4}$ Algunos de los razonamientos que justifican la participación y regulación del Estado dentro del sistema organizativo de libre mercado son expuestos, desde la perspectiva de la ciencia económica, por BARRE, Raymond. Economía política, $5^{a}$ ed. Barcelona: Ariel, 1967, 1v., págs. 165-166. Respecto a las diferentes fórmulas jurídicas de las que puede hacer uso el poder público para participar como operador económico en el mercado, vid. por todos, GALÁN CORONA, Eduardo. "La empresa como destinataria de las normas de defensa de la competencia". Actas de Derecho Industrial, Madrid, 1975, núm. II, págs. 327-336.

${ }^{5}$ Para un análisis sobre los casos jurisprudenciales que han dado lugar a la intervención de los poderes públicos como operadores económicos, así como los límites a los que están sujetos, puede consultarse BACHES OPI, Sergio. La jurisprudencia del Tribunal Supremo en materia de Derecho de Defensa de la Competencia desde la entrada en vigor de la Ley 15/2007. En Baches Opi (Dir.) La Ley 15/2007 de Defensa de la Competencia: balance de su aplicación. Madrid: Ley-Wolters Kluwer, 2010, págs. 88-96; o VALLESPÍN PÉREZ, David. Litigios de consumo: especialidades procesales y acciones colectivas. Barcelona: Bosch, 2018, págs. 28 y ss.

${ }^{6}$ Este aspecto no ha pasado desapercibido por la doctrina, donde no han faltado voces críticas que, a modo de cautela, interpretan en todo caso la posibilidad de actuación pública contenida en el art. 128 CE como una actuación secundaria y subsidiaria de la actividad privada del mercado, reducida al único objetivo de suplir las ineficiencias que la voluntad privada no sea capaz de cubrir (ARIÑO ORTIZ, Gaspar. "La iniciativa pública en la Constitución. Delimitación del sector público y control de su expansión". Revista de Administración Pública, Madrid, 1979, núm. 1, págs. 88-91; y MONEDERO GIL, José Ignacio. "La estructura de la empresa pública en España". Revista de Administración Pública, Madrid, 1982, núm. 99, págs. 124-126). Por el contrario, defienden la posibilidad de actuación de la Administración Pública en el mercado bajo los mismos criterios de concurrencia que el resto de operadores, siempre y cuando exista un interés general, entre otros, FONT GALÁN, Juan Ignacio. Constitución económica y Derecho de la Competencia. Madrid: Tecnos, 1987, pág. 161; y ORTIZ-ARCE, Antonio. "El principio de igualdad en Derecho económico". Revista Española de Derecho Constitucional, Madrid, 1984, año 4, núm. 11, págs. 110-112.
} 
participación de los poderes públicos en el mercado no solo debe ser en régimen de competencia, sino que también debe quedar amparada por estrictas razones de interés público. En caso contrario, se podrían producir situaciones de total ineficiencia y malgasto de recursos que, pese a ser públicos, tienen su coste y sacrificio, no solo por estar sufragados por todos los contribuyentes, sino también por comportar una pérdida de oportunidad, nada insignificante, para otras áreas de la sociedad necesitadas de un mayor desarrollo e inversión.

Este parece ser el criterio sostenido por nuestros órganos jurisdiccionales. Con mayor concreción, nuestro Tribunal Supremo ha supeditado la admisión de cualquier tipo de intervención pública en el mercado, conforme a lo previsto en el art. 128.1 CE, a una previa valoración y ponderación del interés público y a que ésta se realice en un estricto régimen de competencia económica. En esta dirección de pensamiento, resulta especialmente gráfica por lo que respecta a las actuaciones derivadas de las entidades locales para la prestación de servicios básicos municipales, la STS de 24 de junio de 2003 en la que se expone que: "El reconocimiento de la iniciativa pública en la actividad económica rompe con el mito del principio de subsidiariedad que venía rigiendo en el sistema anterior a la Constitución, y que sólo permitía que se produjese esa iniciativa en ausencia de la actividad económica privada en un determinado sector. Es hoy perfectamente posible que se produzca esa iniciativa pública en cualquier actividad económica, siempre que respete el mandato general que a las Administraciones Públicas impone el artículo 103 de la Constitución, cuando señala el límite de que esa actividad se dirija a servir con objetividad los intereses generales" $"$.

Una línea similar también es la recogida por nuestro Tribunal Constitucional, quien en su Sentencia núm. 111/2017, de 5 de octubre, ha llegado a exponer que la libertad empresarial es "compatible con la regulación de condiciones; típicamente las destinadas a proteger a los consumidores, a preservar el medio ambiente, a organizar el urbanismo o a asegurar la «adecuada utilización del territorio por todos». Ahora bien, el artículo 38 CE impone límites a la configuración legislativa de este tipo de condiciones por parte del Estado, las Comunidades Autónomas y los entes locales. Las condiciones que se establezcan deben ajustarse a un canon de razonabilidad en el sentido de que respondan a un objetivo constitucionalmente legítimo y sean idóneas o adecuadas para conseguirlo sin que su intensidad llegue al punto de suponer un impedimento práctico del libre ejercicio de la actividad económica. El canon ha de ser más incisivo si los requisitos o

\footnotetext{
${ }^{7}$ STS (Sala de lo Contencioso-Administrativo, Sección 6a) de 24 de junio de 2003 (RJ 2003/5875). Similares posicionamientos también son recogidos en las siguientes resoluciones: STS (Sala de lo ContenciosoAdministrativo, Sección 4a) de 14 de febrero de 1978 (RJ 1978/4770); STS (Sala de lo ContenciosoAdministrativo, Sección 1a) de 7 de febrero de 1989 (RJ 1989/1081); STS (Sala de lo Contencioso-Administrativo, Sección $1^{\text {a }}$ ) de 10 de octubre de 1989 (RJ 1989/7352); y STS (Sala de lo Contencioso-Administrativo, Sección 4a) de 1 de febrero de 2002 (RJ 2002/1590).
} 
condiciones a la libertad de empresa afectan, no ya a su desarrollo o ejercicio, sino al acceso mismo al mercado" ${ }^{\text {. }}$.

En el seno de nuestro modelo organizativo (pese a configurarse, tal como expone el art. 38 $\mathrm{CE}$, como un modelo de libre mercado), el designio y plena libertad conferida a los agentes privados en la actividad económica no se contempla dentro de nuestro marco constitucional como un fin en sí mismo, sino que resta supeditado, en última instancia, a la prosecución del interés general y al correcto desarrollo de la sociedad (GOIG MARTÍNEZ, 1996, p. 734 y 740). En consecuencia, la libertad económica podrá verse limitada siempre que razones de interés público así lo aconsejen ${ }^{9}$. A este fin, el propio art. 128.2 CE menciona diversos grados de intervención material por los que puede optar la Administración pública para actuar en el mercado. Tales formas concretas de actuación representan un distinto nivel de injerencia que va desde la afectación global a un sector concreto del mercado hasta, llegado el caso, poder decretar la intervención individual a un sujeto económico (DÍEZ-PICAZO, 2013, p 537-538). De hecho, con la intervención de ciertas empresas privadas, la Administración podrá asumir la dirección y organización de éstas en el mercado cuando así lo exijan razones de interés público y se realice a través de instrumento legal (MENÉNDEZ MENÉNDEZ, 1982, p. 41-43). Sin embargo, esta última forma de intervención pública, pese a tener un ámbito de afectación menor, supone un claro límite a otro derecho previsto constitucionalmente, como es el de la libertad de empresa.

En todo caso, los poderes públicos deberán hacer uso de estas fórmulas de acuerdo con los principios de proporcionalidad, idoneidad y mínima afectación (PAZ-ARES RODRÍGUEZ y ALFARO ÁGUILA-REAL, 2008, p. 988-989) ${ }^{10}$. La realización de este juicio de constitucionalidad,

\footnotetext{
${ }^{8}$ STC núm. 89/2017, de 4 de julio (RTC 2017/89). También puede consultarse la STC núm. 53/2014, de 10 de abril (RTC 2014/53), y la STC núm. 30/2016, de 18 de febrero (RTC 2016/30).

${ }^{9}$ Buena prueba de ello puede encontrarse en el conjunto de medidas políticas, económicas y sociales que recientemente han sido adoptadas por el poder ejecutivo con motivo de la crisis sanitaria generada por la COVID19. En el marco del Real Decreto 463/2020 de 14 de marzo por el que se declara el estado de alarma para la gestión de esta situación extraordinaria, resulta especialmente relevante lo dispuesto en su art. 4.3, pues en él se faculta a los Ministerios de Defensa, Interior, Transportes y Sanidad para dictar cuantas órdenes o resoluciones consideren necesarias para garantizar la protección de personas, bienes y lugares. Entre otras medidas, nos parecen especialmente significativas, por su clara limitación al derecho de libertad de empresa y propiedad de los medios de producción, las establecidas en los arts. 13 y 15 del citado Real Decreto. Con el objetivo de garantizar el suministro de los bienes y servicios necesarios para la salud pública, el art. 13 expresamente habilita la intervención y ocupación temporal de industrias, talleres, locales y establecimientos tanto sanitarios como farmacéuticos de titularidad privada. Además, también prevé la posibilidad de imponer prestaciones personales obligatorias a dicho personal, siempre que estén dirigidas a garantizar la salud pública. Igualmente, el art. 15 también contempla que la Administración pueda acordar la intervención de empresas o servicios para asegurar una correcta distribución de los productos de alimentación, así como el funcionamiento de almacenes, centros logísticos y mercados. Dichas medidas de intervención en los sectores sanitarios y de alimentación deben ser complementadas con las directrices previstas en las Órdenes SND/232/2020 de 15 de marzo y SND/275/2020, de 23 de marzo; así como con el articulado general de los Reales Decretos-ley 8/2020 de 17 de marzo, 11/2020 de 31 de marzo, 15/2020 de 17 de marzo, y 16/2020 de 28 de abril.

${ }^{10}$ Esta exigencia y valoración de los diversos elementos imprescindibles para abordar un correcto juicio de proporcionalidad ha sido examinada jurisprudencialmente, entre otras, en las siguientes resoluciones: STC núm. 127/1994, de 5 de mayo (RTC 1994/127); STC núm. 53/2014, de 10 de abril (RTC 2014/53); STC núm. 108/2014,
} 
tal como subraya Díez-Picazo (2013, p. 537-538), es un requisito insalvable para cualquier limitación que afecte a un derecho de transcendencia constitucional, debiendo ponderarse en todo momento el interés público que se pretende alcanzar en relación con el grado de afectación a la libertad de actuación económica (muy especialmente cuando se empleen los mecanismos más cercenadores, como así sucede con la reserva y posible intervención de un sector empresarial). Es más, en la mayoría de supuestos el uso de una u otra medida de intervención no quedará reservado al libre criterio de la Administración, sino que ésta deberá optar de forma imperativa, tras la previa ponderación de los intereses en juego, por aquellas medidas que se presenten menos restrictivas (en caso contrario, se estaría ante una limitación excesiva e injustificada del contenido del art. $38 \mathrm{CE}$ que conculcaría la libertad de empresa) ${ }^{11}$.

\section{EL DERECHO A LA LIBERTAD EMPRESARIAL DE LOS OPERADORES ECONÓMICO-PRIVADOS}

\section{II.1 DELIMITACIÓN Y NATURALEZA JURÍDICA}

Como se ha tenido ocasión de corroborar, nuestro sistema constitucional ha acabado por instaurar, como marco general al que debe circunscribirse toda actividad económica, un sistema descentralizado en el que puede intervenir tanto la iniciativa pública como la privada, de corte neocapitalista, y reconducido a la consecución del interés común (GOIG MARTÍNEZ, 1996, p. 736). Dentro de todo este entramado económico, el propio art. 38 CE remarca expresamente, por su trascendental importancia, el que constituye uno de sus rasgos definitorios: la libertad de empresa.

de 26 de junio (RTC 2014/108); STC núm. 35/2016, de 3 de marzo (RTC 2016/35); así como en las más recientes STC núm. 89/2017, de 4 de julio (RTC 2017/89) y STC núm. 103/2018, de 4 de octubre (RTC 2018/103).

${ }^{11}$ De forma preliminar pueden traerse a colación los pronunciamientos contenidos en la STC núm. 112/2006, de 5 de abril (RTC 2006/112), toda vez que expone que el objetivo último de cualquier juicio de proporcionalidad consiste en "llevar al campo de la libertad de empresa el principio, reconocido siempre en nuestra doctrina, de que, no siendo los derechos que la Constitución reconoce garantías absolutas, las restricciones a que puedan quedar sometidos son tolerables siempre que sean proporcionadas, de modo que, por adecuadas, contribuyan a la consecución del fin constitucionalmente legítimo al que propenden y por indispensables hayan de ser inevitablemente preferidas a otras que pudieran suponer, para la esfera de libertad pública protegida, un sacrificio menor". Puntualizando los argumentos anteriormente citados, véase la STC núm. 53/2014, de 10 de abril (RTC 2014/53), pues ésta añade que "las condiciones de ejercicio de la actividad empresarial, no implican necesariamente que se produzca una afectación a la libertad de empresa que haya de ser considerada contraria a la Constitución, pues la libertad de empresa reconocida en el art. 38 CE exige que las regulaciones públicas que afectan al ejercicio de una actividad empresarial, sin afectar al propio acceso a la misma, sean constitucionalmente adecuadas, es decir no sean en sí mismas irracionales o arbitrarias, y garanticen la igualdad de limitaciones de la actividad económica para las empresas de una misma clase ante cada ordenamiento individualmente considerado". 
La libertad de empresa es una noción que ostenta una naturaleza dual (ÁLVAREZ CONDE, E. y TUR AUSINA, 2016, p. 505). Ello es así, porque si bien se erige, institucionalmente, como un principio inspirador del sistema económico, en cuanto presupuesto indispensable en orden a hacer efectiva la economía de mercado (por lo que forma parte del orden público-económico); no es menos cierto que también adquiere relevancia respecto a los diferentes protagonistas que participan en el mercado (SAINZ MORENO, 1980, p. 497-502). Desde esta perspectiva, de corte individual, la libertad de empresa constituye, como así se ha consagrado en el primer párrafo del art. $38 \mathrm{CE}$, un verdadero derecho subjetivo de carácter socioeconómico ${ }^{12}$.

La libertad de empresa es una manifestación específica del derecho a la propiedad privada reconocido en el art. 33 CE (MARTÍNEZ VAL, 1983, p. 667-668). No obstante, dicha libertad goza de un contenido y sustantividad autónoma ${ }^{13}$. Por lo que hace referencia a su naturaleza jurídica, la libertad de empresa constituye un verdadero derecho subjetivo consagrado en sede constitucional (MENÉNDEZ MENÉNDEZ, 1982, p. 30). Aun cuando el art. 38 CE no contiene ninguna referencia expresa a la libertad de empresa como "derecho" (pues solo se alude, lacónicamente, al término de "libertad"), resulta innegable que la libertad de empresa no puede predicarse como un elemento intrínseco del mercado, y todavía menos del propio sistema económico, ya que dicha libertad, en verdad, no hace referencia a un estado o circunstancia inmóvil y perdurable que acontece, por sí sola, en el espacio económico. De igual modo, tampoco puede entenderse como una circunstancia consustancial ligada al correcto funcionamiento del mercado, como sí lo sería, en su caso, la aparición de la competencia económica. El análisis de la libertad de empresa exige ser contemplado, por tanto, no como un elemento en el que se incorpora toda la estructura económica, sino más bien desde la perspectiva de los agentes que intervienen en el propio mercado.

Así concebida la libertad de empresa, como derecho subjetivo reconocido a aquellos sujetos privados intervinientes en el tráfico empresarial, resulta obligado, a continuación, ponderar la propia ubicación sistemática del art. 38 CE, pues esta es la que, en última instancia, nos permitirá delimitar el grado de concreción y naturaleza constitucional que corresponde a este derecho, tanto en relación a los poderes públicos, como por lo que se refiere al resto de participantes en el tráfico económico.

\footnotetext{
${ }^{12}$ La naturaleza dual de la libertad de empresa, en cierto modo, también puede entreverse en algunas resoluciones del TS. A título de ejemplo pueden consultarse, entre otras, la STS (Sala de lo Contencioso-Administrativo, Sección 6a) de 10 de noviembre de 1997 (RJ 1997/7947); la STS (Sala de lo Contencioso-Administrativo, Sección $7^{\mathrm{a}}$ ) de 27 de abril de 2001 (RJ 2001/2867) en la que se expone que: "la libertad de empresa, junto a su dimensión subjetiva, tiene otra objetiva e institucional, en cuanto elemento de un determinado sistema económico, y se practica dentro de un marco general configurado por reglas que ordenan la economía de mercado, entre ellas las que tutelan los derechos de los consumidores u ordenan un sector como el de los juegos de azar, en el que las potestades administrativas de intervención y control están sobradamente justificadas por los intereses que en el mismo subyacen"; o también la STS (Sala de lo Civil, Sección 1ª) núm. 1136/2007, de 25 de octubre (RJ 2007/8638).]

${ }^{13}$ ÁLVAREZ CONDE, E. y TUR AUSINA, R. Derecho Constitucional, ob. cit., pág. 505.
} 
El art. 38 CE se incardina en la Sección Segunda del Capítulo Segundo del Título Primero de la Constitución, denominado "De los derechos y deberes de los ciudadanos", encontrándose ubicados en aquella sección la mayor parte de los derechos de contenido económico-patrimonial (vgr. derecho a la propiedad, derecho de colegiación y ejercicio de profesiones liberales). En consecuencia, se trata de un derecho subjetivo que goza de un reconocimiento constitucional directo. Sin embargo, la libertad de empresa, pese a incluirse en el Capítulo Segundo de la Constitución, el cual versa sobre "De los derechos fundamentales", carece de un verdadero carácter fundamental, puesto que los distintos derechos recogidos en el Título Segundo de la Constitución no comparten idéntica categoría jurídica (ROJO FERNÁNDEZ-RÍO, 1983, p. 325-326).

El derecho económico que ahora nos ocupa no tiene un verdadero carácter fundamental, pues a pesar de estar reconocido por el texto constitucional, lo cierto es que la libertad de empresa queda fuera de la Sección Primera del Capítulo Segundo (donde se consagran los derechos fundamentales stricto sensu). Por consiguiente, no quedará amparada por la máxima protección constitucional prevista en el segundo párrafo del art. $53 \mathrm{CE}$, no pudiendo ser objeto de protección jurisdiccional por vía sumaria, así como tampoco fundamentar una eventual demanda de amparo constitucional.

Por el contrario, por aplicación del apartado primero del art. $53 \mathrm{CE}$ sí resulta factible concluir, en primer lugar, que la máxima expresión de la libertad de empresa se convierte en un límite infranqueable y de obligado respeto por el legislador ordinario ante cualquier desarrollo normativo posterior; en segundo lugar, que todos los poderes públicos deben respetar, en sus actuaciones, su contenido esencial (eficacia vertical directa); en tercer lugar, que dicho derecho se acompaña, en cuanto garantía formal, de una reserva de ley ordinaria; y, por último, que toda modificación o supresión que pretenda realizarse por efecto de un "viraje político", únicamente podría afrontarse mediante un proceso de reforma constitucional (esto es, por los trámites de la reforma ordinaria previstos en los arts. 87 y $167 \mathrm{CE})$.

En esta dirección de pensamiento, por ejemplo, resulta especialmente gráfica la STC 83/1984 $4^{14}$, de 24 de julio, según la cual: "no hay un contenido esencial constitucionalmente garantizado de cada profesión, oficio o actividad empresarial concreta; el derecho constitucionalmente garantizado en el art. 35.1 no es el derecho a desarrollar cualquier actividad, sino el de elegir libremente profesión u oficio, ni en el art. 38 se reconoce el derecho a acometer cualquier empresa, sino solo el de iniciar y sostener en libertad la actividad empresarial, cuyo ejercicio está disciplinado por normas de muy distinto orden”.

\footnotetext{
${ }^{14}$ STC núm. 93/1984, de 24 de julio (RTC 1984/93). El mismo pronunciamiento también aparece contemplado en resoluciones posteriores del Tribunal Constitucional, entre otras: STC núm. 225/1993, de 8 de julio (RTC 1993/225); STC núm. 112/2006, de 5 de abril (RTC 2006/112); ATC núm. 71/2008, de 26 de febrero (RTC 2008/71); o en la más reciente STC núm. 103/2018, de 4 de octubre (RTC 2018/103).
} 
No debe olvidarse que al consagrarse la iniciativa económica privada como una pieza fundamental sobre la que recaen, en primera instancia, las tareas de producción y distribución de bienes y servicios dentro del sistema organizativo del que nos hemos dotado (FIKENTSCHER, 1984, p. 475-476), parece razonable pensar que junto a esta atribución de responsabilidad a los agentes privados, éstos, en paralelo, también vean suavizada dicha profunda carga mediante la preservación de un espacio que, a modo de mínima garantía, les permita cumplir con esta función social, pero sin desatender lo que, en realidad, constituyen sus preferencias y objetivos más particulares (DÍEZ-PICAZO, 2013, p. 537-540).

\section{II.2. ÁMBITO DE APLICACIÓN OBJETIVO}

La dicción literal del art. 38 CE, al reconocer el derecho a la libertad de empresa en el marco de la economía de mercado, no efectúa ninguna concreción en orden a su contenido, así como tampoco detalla las condiciones de su ejercicio, requisitos y alcance. Nuestro legislador constitucional se ha limitado tan solo a proclamar la libertad de empresa como un derecho subjetivo dentro de nuestro esquema económico, de tal forma que estamos ante un derecho de configuración legal (donde es necesaria una interpositio legislatoris en aras a determinar tanto su régimen jurídico, como las condiciones para su ejercicio) ${ }^{15}$.

Por lo que respecta a su delimitación objetiva, debe tenerse en cuenta que la libertad de empresa cristaliza la máxima expresión de las libertades públicas dentro de la esfera económica (PAZ-ARES RODRÍGUEZ y ALFARO ÁGUILA-REAL, 2008, p. 981). El bien jurídico a proteger mediante la libertad de empresa no es otro que la capacidad y libre disposición de los sujetos particulares en orden a intervenir en todas y cada una de las actividades económicas que pueden tener cabida dentro de nuestro modelo organizativo. Los términos utilizados por el art. $38 \mathrm{CE}$ permiten llegar a conceptualizar la libertad de empresa como aquella libertad reconocida a los particulares en atención a la cual se les permite destinar toda una serie de bienes y recursos para el desempeño de actividades económicas, con el objetivo de producir e intercambiar bienes y servicios de conformidad con las pautas organizativas preestablecidas, así como obtener un beneficio económico (BASSOLS COMA, 1985, p. 137).

En consecuencia, la libertad de empresa se presenta como una "cápsula de protección" de la iniciativa económica en el ámbito individual (FIKENTSCHER, 1984, p.481). Recae a favor de aquellos sujetos a los que, por regla general, el sistema económico encomienda la actividad

15 STC núm. 37/1981, de 16 de noviembre (RTC 1981/37); STC núm. 112/2006, de 5 de abril (RTC 2006/112); STC núm. 135/2012, de 19 de junio (RTC 2012/135); STC núm. 53/2014, de 10 de abril (RTC 2014/53); o STC núm. 35/2016, de 3 de marzo (RTC 2016/35). 
productiva; pero también actúa como garantía ante cualquier exceso de intervención por parte de la Administración (PAZ-ARES RODRÍGUEZ y ALFARO ÁGUILA-REAL, 2008, p. 988)². De ahí, precisamente, que pueda afirmarse que nuestro sistema económico constitucional haya optado por pretender congeniar la intervención privada con el respaldo de la iniciativa pública, ya que la libertad de empresa, sin alejarse de su concepción como derecho subjetivo, también se erige como garantía de la propia existencia de la actividad privada, alejándola de injerencias arbitrarias por parte del poder público. Todo ello, claro está, sin olvidar que la libertad de empresa y, por ende, la iniciativa privada, también resultan afectadas por los límites del interés público y de la planificación y ordenación económica (MENÉNDEZ MENÉNDEZ, 1982, p. 39-41).

Como así se deduce de nuestra jurisprudencia constitucional en orden a la delimitación del contenido que cabe atribuir al derecho de libertad de empresa, dos son los actos clave en los que se materializa este derecho subjetivo: el primero, comprensivo del instante previo a acceder y constituirse en operador jurídico ("iniciar"); y el segundo relativo a todo el itinerario propio de la actividad ("sostener"). Por consiguiente, bien puede afirmarse que el derecho a la libertad de empresa es un derecho subjetivo de desarrollo continuo, pues su ejercicio no se agota en unidad de acto (constitución como operador económico y acceso al mercado), sino que el despliegue del art. $38 \mathrm{CE}$, por el contrario, también debe acompañar a los sujetos implicados a lo largo de toda su trayectoria empresarial. En coherencia con este desarrollo continuo que se acaba de exponer, la libertad de empresa tampoco se manifiesta de una única forma, sino que aparece reflejada de modo sucesivo mediante una pluralidad de actos de contenido muy variado (en función de la etapa en la que se encuentre su titular, así como de la voluntad que pretenda expresar en cada caso concreto).

De conformidad con lo anterior, es posible individualizar tres grandes etapas, diferenciables pero consecutivas, que envuelven el desarrollo de esta libertad constitucional. La primera de ellas, relacionada con el "inicio", vendría a resguardar, desde una perspectiva ex ante, el desempeño del ejercicio profesional, la capacidad de todo particular para decidir y valorar si desea constituirse en operador económico con el fin de emprender una actividad empresarial (vgr. las decisiones acerca de la tipología jurídica, la selección del sector donde operar, las características de los bienes a ofrecer, la determinación de los recursos afectos a la actividad y los riesgos a asumir). En esta etapa inicial de valoración, los agentes interesados en participar del tráfico económico únicamente deben sortear y hacer frente a las barreras de entrada que son propias de la industria en que deciden intervenir, esto es, los inconvenientes de origen natural e intrínseco, propios del funcionamiento del

\footnotetext{
${ }^{16}$ En esta misma dirección de pensamiento, sirva de ejemplo, por todas, la STC núm. 112/2006, de 5 de abril (RTC 2006/112): "en el marco de una economía de mercado, donde este derecho opera como garantía institucional, el reconocimiento a los particulares de una libertad de decisión no solo para crear empresas y, por tanto, para actuar en el mercado, sino también para establecer los propios objetivos de la empresa y dirigir y planificar su actividad en atención a sus recursos y a las condiciones del propio mercado".
} 
sector y que se presentan, con carácter general, a todos y cada uno de sus competidores. Cualquier obstáculo de origen externo a la propia inercia económica (bien legal o de reacción por parte del resto de empresas competidoras) que dificultase o impidiera su acceso, sería, en todo caso, susceptible de conculcar el derecho subjetivo consagrado en el art. $38 \mathrm{CE}$ (incluso instantes antes de haber accedido materialmente al mercado). De hecho, en esta etapa ya puede apreciarse una estrecha vinculación entre la libertad de empresa y uno de los ámbitos de actuación propios del Derecho de la Competencia, como es el relativo a las políticas de promoción de la competencia a cargo de los poderes públicos, pero bajo la orientación de los órganos especializados en la materia, con los que contribuir al dinamismo del mercado y facilitar la entrada, permanencia y salida continua de sus operadores (SAMUELSON y NORDHAUS, 1991, p. 643-644).

La segunda de las etapas de la libertad de empresa implica traer a colación que el art. $38 \mathrm{CE}$ también debe velar para que aquellos sujetos que ya han decidido intervenir en el mercado, puedan, a posteriori, implementar y desarrollar, con carácter estable y permanente, su actividad empresarial en un entorno lo más neutro y aséptico posible. Para ello es imprescindible que todos los competidores de un mismo sector permanezcan en idénticas condiciones, tanto positivas (vgr. acceso a incentivos, ayudas o subvenciones) como negativas (vgr. restricciones, adaptaciones, mejoras o prohibiciones), pues las diferencias entre ellos solo debieran derivar del número de recursos a destinar, su calidad, y la gestión de los mismos (JIMÉNEZ CARDONA, 2018, p. 1318).

La tercera etapa evolutiva que acompaña al ejercicio del derecho a la libertad de empresa supone tomar en consideración que, en atención al art. $38 \mathrm{CE}$, también debe garantizarse a los titulares la posibilidad de salir y cesar en su actividad comercial en cualquier momento y con independencia de su resultado. En estos casos de "desistimiento empresarial”, su titular debe hacer frente, únicamente, al coste de las barreras de salida que sean consustanciales a la propia inercia del ciclo del mercado, a la inversión realizada por el operador (junto a la pérdida de oportunidad que ello implica), y a las posibles responsabilidades civiles que pudieran derivarse de la puesta en marcha del negocio.

Por todo lo que se acaba de exponer, la libertad de empresa, desde una visión abstracta (o de afectación grupal), permite que el proceso productivo se desarrolle en pleno régimen de libre mercado, siendo lo cierto que éste, a su vez, conduce a que las empresas que hayan decidido intervenir en el mercado se esfuercen en obtener la mejor posición posible gracias a la conjugación armónica de sus elementos disponibles (recursos internos) y de la mejor adaptación a las características del terreno de juego de su actividad (estado del sector) (SPULBER, 2013, p. 46-47). De este modo, el derecho a la libertad de empresa no solo contiene una garantía de actuación, sino también genera un deber para su titular, ya que éste, en cuanto sujeto económico que ha decidido voluntariamente acogerse a este derecho, mediante el desempeño de una actividad económica, 
queda obligado, igualmente, a ejecutarlo de una forma que no suponga contrariar el espíritu competitivo del resto de los agentes concurrentes (OROMÍ VALL-LLOVERA, 2016, p. 101-102).

De otra parte, conseguir un espacio de intercambio económico que se encuentre regido por las reglas de la libre competencia solo es posible si los agentes económicos tienen plena autonomía para elegir cómo desean presentarse en el tráfico mercantil y cuáles van a conformar sus líneas principales de actuación (MORALES BARCELÓ, 2020, p. 2-3). Es por ello que el derecho a la libertad de empresa no solo debe relacionarse con la necesidad de garantizar el acceso de cualquier particular, ya sea persona física o jurídica, a un mercado determinado, posibilitándole operar en él; sino que también debe vincularse con la obligación de garantizarle toda una serie de facultades de decisión y dirección con las que debe regir la actividad mercantil libremente elegida ${ }^{17}$.

De ahí, precisamente, que pueda decirse que la libertad de empresa resguarda todo un amplio elenco de facultades que son inherentes a los tres pilares fundamentales sobre los que se sustenta todo negocio: la implementación de un planteamiento estructural, la gestión de recursos humanos y el desarrollo de políticas en materia de financiación (NAVAS LÓPEZ y GUERRAS MARTÍN, 2016, p. 203-206). En consecuencia, su titular deberá ostentar toda una serie de facultades que le permitan decidir cómo desea comportarse en el mercado, por ejemplo, mediante la elección del sector en el que desea competir, de la línea de productos a ofrecer, o del planteamiento estratégico de la propia empresa (vgr. la diversificación de negocio, la penetración de mercado, la entrada en nuevos mercados o, incluso, la apuesta por la internacionalización).

De igual forma, la libertad de empresa se manifiesta, de una parte, en el otorgamiento de todo un conjunto de facultades de dirección de personal que permitan implantar una política de contratación y retribución más adecuada y ajustada a las necesidades y capacidades de la empresa (vgr. política de contratación, desarrollo personal y promoción, identificación de perfiles necesarios, selección discrecional del personal, imposición de las condiciones de trabajo, selección de la política retributiva); y, de otra, en aquel otro elenco de facultades relacionadas con los recursos e inversiones que el titular está dispuesto a poner a disposición - y riesgo - de su organización (vgr. seleccionar los recursos propios que va a destinar a la actividad empresarial o, llegado el caso, identificar aquellas fuentes de financiación externa que estime imprescindibles).

\footnotetext{
${ }^{17}$ En este sentido, a título de ejemplo, véanse, entre otras, la STC núm. 225/1993, de 8 de julio (RTC 1993/225); la STC núm.112/2006, de 5 de abril (RTC 2006/112); el ATC núm. 71/2008, de 26 de febrero (RTC 2008/71); o la STC núm. 96/2013, de 23 de abril (RTC 2013/96). Por su parte, el Tribunal Supremo en su STS (Sala de lo Civil, Sección $1^{\text {a }}$ ) núm. 999/2005, de 20 de diciembre (RJ 2006/288), con motivo de un posible conflicto entre un derecho de marca internacional y la libertad de empresa, dispone que "la libertad de empresa se identifica con el derecho subjetivo a acometer y desarrollar actividades económicas, además de con un principio de ordenación económica por virtud del cual corresponde a los empresarios decidir los objetivos de su empresa y llevar a cabo la correspondiente planificación".
} 
Y todo ello en el bien entendido sentido de que todas las facultades que, en definitiva, permiten la libre decisión y dirección empresarial, no deben relacionarse tan solo con el momento de acceso al mercado, sino que también deben permanecer mientras se desarrolle la actividad empresarial hasta el momento de su finalización.

\section{II.3. ÁMBITO DE APLICACIÓN SUBJETIVO}

En lo que respecta al ámbito subjetivo que despliega tal libertad económica dentro de nuestro ordenamiento jurídico, el primer inciso del art. $38 \mathrm{CE}$, bajo la mención a la libertad de empresa, parece resguardar un espacio dentro del cual sus destinatarios ostentan plena autonomía y poder de disposición sobre los diferentes elementos que conforman su actividad empresarial, de tal modo que, siempre que el ejercicio de dicha libertad no resulte contrario a los postulados básicos del sistema económico, los destinatarios quedarán resguardados de cualquier injerencia o intervención pública.

Sin embargo, el art. 38 CE hace uso de una terminología impersonal. De hecho, al emplear la fórmula verbal reflexiva "se reconoce", nada indica acerca de aquellos sujetos que puedan ser titulares de este derecho empresarial. Por ello, no existe ningún impedimento para afirmar que pueden ser titulares del derecho a la libertad de empresa todas las personas que ostentan la nacionalidad española, siempre y cuando cumplan con los requisitos generales de capacidad establecidos, genéricamente, en la normativa correspondiente ${ }^{18}$

Tampoco parece ser una cuestión merecedora de debate la extensión del art. 38 CE al resto de personas -tanto físicas como jurídicas- que ostenten la nacionalidad de alguno de los Estados miembros de la Unión Europea. De acuerdo con los principios de primacía y efectividad que rigen en el Derecho comunitario y, en última instancia, con el objetivo final de la UE en materia económica (establecimiento de un espacio que permita la creación y consolidación de un mercado único), no existe ningún argumento de peso que impida que cualquier ciudadano comunitario inicie su aventura empresarial en otro mercado nacional (más allá, por supuesto, de cumplir con los requisitos exigidos por la normativa estatal, autonómica y municipal a sus nacionales, tanto de carácter general como en función del sector de la actividad implicado).

Sin embargo, la falta de concreción subjetiva en la que incurre la redacción del art. 38 CE se dibuja con mayor polémica respecto a los sujetos que ostentan alguna nacionalidad de terceros países de la Unión Europea. A día de hoy, nuestro máximo intérprete constitucional no se ha

\footnotetext{
${ }^{18}$ Las reglas generales relativas a la capacidad de obrar necesaria para el ejercicio del comercio se encuentran recogidas, para los empresarios personas físicas, en los arts. 4 y 5 del Código de Comercio (junto con la normativa genérica prevista en los arts. 322 y ss. del Código Civil), mientras que para las personas jurídicas deberá acudirse a la normativa encargada de regular cada una de las tipologías sociales en las que pueden constituirse.
} 
pronunciado específicamente sobre el alcance del art. $38 \mathrm{CE}$ en relación a los ciudadanos con nacionalidad extracomunitaria. Ante esta situación, la solución ha de pasar, como señala Aja Fernández (2012, p. 314-317) por una interpretación analógica de la doctrina jurisprudencial que nuestro Tribunal Constitucional ha ido estableciendo respecto a la delimitación de algunos de los derechos previstos en la CE (como así ha sucedido con el derecho a la salud, el derecho de igualdad, el derecho a la educación, o incluso el derecho de huelga y sindicación laboral); y tomando como punto de partida lo dispuesto en el art. 13.1 CE “los extranjeros gozarán en España de las libertades públicas que garantiza el presente Título en los términos que establezcan los tratados y la ley”.

De acuerdo con la doctrina jurisprudencial sobre los derechos previstos en la Constitución (tanto los de naturaleza fundamental, como los de mero reconocimiento constitucional - entre los que se encuentra el art. $38 \mathrm{CE}$-), nuestro TC ha interpretado el art. 13.1 CE haciendo uso de una construcción jurídica atendiendo al grado y cercanía que presentan los diversos derechos subjetivos con la dignidad de la persona (especialmente apreciable, a título de ejemplo, en la STC núm. 107/1984 de 23 de diciembre) $)^{19}$. De tal modo se ha establecido una triple categoría de derechos subjetivos: aquellos que aparecen estrechamente ligados al principio de igualdad; una segunda categoría de derechos, referida a diferentes libertades que mueven a los ciudadanos en las diversas esferas de su vida (tanto entre particulares como en relación con los poderes públicos) y cuyo contenido dependerá del régimen configurado por el legislador; y en último lugar, aquellos otros derechos que aparecen ligados a la nacionalidad (AJA FERNÁNDEZ, 2012, p. 315).

Al hilo de esta clasificación nuestro TC concluye, de un lado, que únicamente constituirían verdaderos derechos fundamentales, innegables a cualquier individuo debido a su condición de persona, aquellos que constituyeran ser manifestaciones directas del derecho a la vida; y, de otro, que el resto de derechos, pese a su relevancia y reconocimiento constitucional, es lo cierto que pueden ser objeto de delimitación en función del estatus administrativo de los ciudadanos, pudiendo incluso ser limitados a aquellas personas que se hallasen en situación irregular. Siendo esto así, bien puede afirmarse que el derecho a la libertad de empresa, como manifestación de la libertad individual de las personas en el tráfico económico, carece de esa estrecha y especial vinculación con el núcleo más directo de la dignidad y vida humana.

\footnotetext{
${ }^{19}$ STC núm. 107/1984, de 23 de noviembre (RTC 1984/107). Esta diferenciación entre los diversos derechos constitucionales constituye una línea jurisprudencial consolidada por el TS, también apreciable, entre otras, en sus STS (Sala de lo Contencioso-Administrativo, Sección 7ª) de 21 de julio de 1995 (RJ 1995/5948); STS (Sala de lo Contencioso-Administrativo, Sección 7 ${ }^{\text {a }}$ ) de 4 de marzo de 1996 (RJ 1996/2169); STS (Sala de lo ContenciosoAdministrativo, Sección $7^{\text {a }}$ ) de 28 de mayo de 1996 (RJ 1996/4651); y STS (Sala de lo ContenciosoAdministrativo, Sección 6 ${ }^{\text {a }}$ ) de 18 de marzo de 1998 (RJ 1998/2826); así como por los diferentes TSJ de las CCAA, entre otras resoluciones, sirvan de ejemplo: la STSJ de Cataluña (Sala de lo Contencioso-Administrativo, Sección $2^{\mathrm{a}}$ ) núm. 445/2003, de 20 de marzo (RJCA 2004/140); la STSJ de Madrid (Sala de lo Contencioso-Administrativo, Sección $1^{\text {a }}$ ) núm. 877/2005, de 6 de julio (RJCA 2005/867); o la STSJ de Castilla y León (Sala de lo ContenciosoAdministrativo, Sección 1ª) núm. 1475/2008, de 23 de junio (JUR 2009/43842).
} 
Por consiguiente, el art. $38 \mathrm{CE}$ solo confiere un derecho subjetivo de naturaleza económica a los ciudadanos extracomunitarios que se hallen en situación regular en el territorio español. El ejercicio del art. $38 \mathrm{CE}$ por parte de ciudadanos extracomunitarios puede, a su vez, resultar afectado, como así sucede, por importantes límites a su contenido y facultades derivados de la exigencia de determinar previamente el sector de actividad, así como por la restricción de la actividad empresarial a un territorio no superior al de una Comunidad Autónoma. Asimismo, la titularidad del derecho a la libertad de empresa a favor de ciudadanos extracomunitarios también puede quedar a expensas del cumplimiento de toda una serie de requisitos adicionales a los exigibles al resto de ciudadanos, tanto nacionales como comunitarios, que aparecen específicamente contemplados en la normativa de extranjería ${ }^{20}$

\section{II.4. LIMITACIONES Y RESTRICCIONES AL EJERCICIO DEL DERECHO A LA LIBERTAD EMPRESARIAL}

Hasta lo aquí expuesto, el derecho a la libertad de empresa confiere toda una serie de facultades vinculadas con la dirección empresarial y orientadas, en cada caso, a la idea de negocio que pretende desarrollarse en el mercado. No obstante, interpretar el derecho a la libertad de empresa como aquel derecho que confiere a cada particular un poder concreto e incondicionado para actuar en el mercado por su cuenta y riesgo personal, mediante la creación de una empresa específica y determinada, supondría, a todas luces, una visión equívoca y no respetuosa con lo dispuesto en el propio art. $38 \mathrm{CE}$.

Tal como sucede con los restantes derechos subjetivos consagrados en nuestro ordenamiento jurídico, ya tengan carácter fundamental o no, el contenido del derecho a la libertad de empresa también puede someterse a ciertos límites o restricciones provenientes de la potestad normativa de los poderes públicos que, en su caso, podrán restringir el ejercicio del derecho

\footnotetext{
${ }^{20}$ Esta misma conclusión es, en cierto modo, recogida por el legislador si se atiende conjuntamente a la Ley Orgánica 4/2000, de 11 de enero, sobre derechos y libertades de los extranjeros en España y su integración social, así como a su reglamento de desarrollo (Real Decreto 557/2011, de 20 de abril, por el que se aprueba el Reglamento de la Ley Orgánica 4/2000, sobre derechos y libertades de los extranjeros en España y su integración social). Concretamente, en los arts. 36 y 37 LODLE (complementados con los arts. 62 a 68 del Reglamento) se exige, para los supuestos de trabajo por cuenta propia, toda una serie de requisitos adicionales que plantean serios obstáculos, ni siquiera de índole burocrática, para el ejercicio de la actividad empresarial en España. Todas estas exigencias, con carácter general, pueden reconducirse a las siguientes: ausencia de antecedentes penales del solicitante en los últimos cinco años; concreción del sector de actividad y desarrollo de la actividad en una extensión máxima equivalente al territorio de una Comunidad Autónoma; y solicitud de una autorización administrativa previa, cuya concesión, por otra parte, únicamente podrá tener lugar si se acreditan, entre otros requisitos, la existencia de un nivel de inversión que garantice el desarrollo de la actividad mercantil, la previsión de la creación hipotética de empleo derivada de la actividad, así como la acreditación de tener el solicitante recursos suficientes para, además de poner en marcha la actividad empresarial, garantizar su propio mantenimiento y alojamiento, de acuerdo con los indicadores establecidos en el art. 54 del Reglamento de desarrollo.
} 
empresarial, siempre que exista un interés público y no se desnaturalice su contenido esencial, de acuerdo con lo dispuesto en otros preceptos constitucionales (arts. 40, 128 y $131 \mathrm{CE}$ ); y, que, incluso para sectores muy concretos y en circunstancias particulares, en cuanto exigencia del interés público, podría alcanzar su total exclusión.

Ante la falta de una mínima concreción normativa que sirva para perfilar el contenido mínimo de la libertad de empresa (más allá de dejar entrever que ésta desempeña un papel fundamental e inamovible dentro de nuestro sistema económico), ha correspondido a los órganos jurisdiccionales la determinación del contenido esencial del art. $38 \mathrm{CE}$, así como de los contornos que deben caracterizar su ejercicio. De hecho, en la práctica, nuestra jurisprudencia más que centrarse en analizar el contenido de este derecho, lo que ha hecho es apostar por señalar todos aquellos aspectos que no pueden enmarcarse dentro de la esfera de su ejercicio ${ }^{21}$.

La libertad de empresa consagrada en el art. 38 CE no es un derecho absoluto, sino sometido a límites, siendo lícita la imposición de limitaciones y restricciones por razón de su función social. Dichos límites vienen marcados por normas de muy distinto orden, tanto estatales como autonómicas ${ }^{22}$. Ello es así, porque dicha libertad de empresa "no ampara entre sus contenidos - ni en nuestro ordenamiento ni en otros semejantes- un derecho incondicionado a la libre instalación de cualesquiera establecimientos comerciales en cualquier espacio y sin sometimiento alguno al cumplimiento de requisitos y condiciones, haciendo caso omiso de las distintas normativas estatales, autonómicas, locales- que disciplinan múltiples aspectos de relevancia económica como, entre otros, el comercio interior y la ordenación del territorio ${ }^{, 23}$. Por tanto, el derecho a la libertad de empresa no presenta un contenido inmóvil y permanente, sino que debe ser interpretado de acuerdo con el contexto social en el que se desenvuelve: "la libertad de empresa, protegida por el artículo 38 de la Constitución, debe tomarse en consideración atendiendo a su función dentro de la sociedad"24.

\footnotetext{
${ }^{21}$ Véase, por todas, la STC núm. 83/1984, de 24 de julio (RTC 1984/83).

${ }^{22}$ STC núm. 37/1981, de 16 de noviembre (RTC 1981/37). Similares pronunciamientos son también recogidos en la emblemática STC núm. 83/1984, de 24 de julio (RTC 1984/83); así como en las posteriores STC núm. 152/2003, de 17 de julio (RTC 2003/152); STC núm. 18/2011, de 3 de marzo (RTC 2011/18); STC núm. 135/2012, de 19 de junio (RTC 2012/135); STC núm. 96/2013, de 23 de abril (RTC 2013/96); y STC núm. 86/2017, de 4 de julio (RTC 2017/86). En parecidos términos también se ha pronunciado nuestro Tribunal Supremo en las STS (Sala de lo Civil, Sección $1^{\text {a }}$ ) núm. 1169/2006, de 24 de noviembre (RJ 2007/262); STS (Sala de lo ContenciosoAdministrativo, Sección 3a) de 9 de marzo de 2015 (RJ 2015/1108); STS (Sala de lo Contencioso-Administrativo, Sección $3^{\text {a }}$ ) núm. 999/2015, de 20 de diciembre (RJ 2015/288); ATS (Sala de lo Contencioso-Administrativo, Sección $1^{\text {a }}$ ) de 9 de marzo de 2018 (RJ 2018/968); o en las más recientes sentencias del TS (Sala de lo ContenciosoAdministrativo, Sección $2^{a}$ ) relativas al impuesto autonómico sobre el daño medioambiental en relación con las actividades empresariales que resulten contaminantes para el medio ambiente: STS núm. 1506/2018, de 16 de octubre (RJ 2018/4637) y STS núm. 1507/2018, de 16 de octubre (RJ 2018/4634).

${ }^{23}$ STS (Sala de lo Contencioso-Administrativo, Sección 4a ) de 17 de mayo de 2005 (RJ 2005/5720).

${ }^{24}$ STS (Sala de lo Contencioso-Administrativo, Sección 3a) núm. 1193/2017, de 7 de julio (RJ 2017/3630).
} 
Desde una perspectiva material relativa a las injerencias normativas a las que puede quedar sujeta la actividad empresarial, nuestra más alta jurisprudencia ha reconocido que cualquier regulación, siempre que descanse en la consecución de un interés social o general, constituye, como regla general, un límite tolerable y admisible por el art. $38 \mathrm{CE}$. Es más, el propio TC no solo se ha mostrado favorable a aceptar la regulación en la mayoría de los sectores, sino que hasta ha remarcado su connotación positiva hasta el extremo de calificarla como aquella herramienta encargada de regular el ejercicio del derecho constitucional consagrado en el art. $38 \mathrm{CE}$, resultando ser una pieza muy útil para delimitar y precisar el contenido y las facultades que no vienen expresamente indicadas en el propio precepto constitucional ${ }^{25}$.

A pesar de que todo intento de regulación encaminado a establecer por vez primera o modificar el marco normativo de la actividad podría constituir una afectación del derecho a la libertad de empresa, por cuanto genera la obligación de cumplir con toda una serie de requisitos (con sus costes no sólo económicos sino también organizativos y de pérdida de oportunidad, que los propios empresarios deberán sufragar para poder seguir operando en el mercado); lo cierto es que la doctrina constitucional, pese a la frecuente actividad jurisdiccional de los agentes afectados, en raras ocasiones ha considerado que ello vulnere el núcleo esencial de la libertad de empresa ${ }^{26}$, pues ha estimado que ello constituye una suerte que los operadores económicos deben estar dispuestos a correr por resultar inherente al riesgo empresarial en el que se desenvuelve su actividad ("riesgo regulatorio") $)^{27}$.

Acorde con lo señalado por esta doctrina constitucional, la intervención normativa será plenamente compatible con la libertad de empresa siempre que respete su contenido esencial y se fundamente bien en motivos de orden y seguridad públicos (como así sucede con la normativa sobre control de calidad de productos o sobre la composición de los mismos); bien en asegurar la distribución de un bien o la prestación de un servicio en todo el territorio nacional por razones de interés general (supuestos de prestación de servicios básicos tales como telefonía, servicios postales, electricidad o abastecimiento de aguas, en los que se imponen ciertas obligaciones y condiciones adicionales de servicio de carácter imperativo); o bien simplemente cuando la normativa cumpla con un estricto fin de ordenación de la actividad (como, por ejemplo, con la fijación de horarios de

\footnotetext{
${ }^{25}$ En esta dirección interpretativa, por todas, véanse: STC núm. 225/1993, de 25 de julio (RTC 1993/225); STC núm. 280/2015, de 17 de diciembre (RTC 2015/280); STC núm. 30/2016, de 18 de febrero (RTC 2016/30); y también la STS (Sala de lo Contencioso-Administrativo, Sección 3 $3^{\text {a }}$ ) núm. 1193/2017, de 7 de julio (RJ 2017/3630).

${ }^{26}$ Algunos de los supuestos que han dado pie a la jurisprudencia a declarar una vulneración directa del art. $38 \mathrm{CE}$ pueden consultarse en las siguientes resoluciones: STC núm. 88/1986, de 1 de julio (RTC 1986/88); STC núm. 109/2003, de 5 de junio (RTC 2003/109); STS (Sala de lo Contencioso-Administrativo, Sección $5^{\text {a }}$ ) de 31 de enero de 2001 (RJ 2001/1726); y STSJ de Cataluña (Sala de lo Contencioso-Administrativo, Sección $3^{\mathrm{a}}$ ) núm. 1077/2000, de 21 de diciembre (RJCA 2001/445)

${ }^{27}$ Vid. STC núm. 30/2016, de 18 de febrero (RTC 2016/30).
} 
apertura al público, tipología de establecimientos con unos requisitos mínimos de espacio, ventilación y servicios, limitación de la actividad en función de la clase de establecimiento, supeditación de la actividad a una previa autorización o comunicación administrativa previa, entre otros $)^{28}$.

Si bien la actividad regulatoria, desde un plano estrictamente teórico, constituye un elemento intrusivo y ajeno que interfiere, cuando no distorsiona, en el propio funcionamiento del mercado (bien puede actuar como una nueva barrera de entrada y desalentar el acceso de posibles sujetos interesados, o bien puede producir la desaparición de aquellos operadores que estando en el mercado carecen de la capacidad financiera suficiente con la que hacer frente a los requisitos exigidos); lo cierto es que tal afectación de las libertades individuales no tiene relevancia jurídica suficiente cuando sea individualizable en el tiempo, persiga la tutela de un interés superior, y presente una mínima entidad ${ }^{29}$.

Resultará apreciable el elemento de la mínima afectación cuando los operadores económicos tengan la posibilidad de subsanar el coste sufrido, es decir, no se vean privados de su capacidad de resarcimiento. Una vez adecuados todos los elementos de su actividad empresarial a la normativa, el esfuerzo financiero podrá verse compensado por los rendimientos económicos de su actividad empresarial. Por lo tanto, la capacidad de resarcimiento, que en última instancia no dejar ser un fiel reflejo de la capacidad de supervivencia que acompaña a las empresas más fuertes y dotadas de una mejor posición competitiva, quedará determinado por criterios estrictamente de mercado, teniendo en todo momento los operadores afectados la posibilidad de lucrarse y resarcirse de los costes que las reformas normativas les hayan generado (VALLESPÍN PÉREZ, 2018, p. 7475).

De este modo, pese a la intromisión de la normativa como cuerpo extraño a la mecánica del mercado, ello no impide que éste vuelva a requilibrarse en su propio ecosistema porque, de nuevo, el factor último de decisión que determinará la capacidad de afrontar o no tal impedimento

\footnotetext{
${ }^{28}$ En términos muy esclarecedores y respecto a la ordenación de la actividad comercial, véase, por todas, la STS (Sala de lo Contencioso-Administrativo, Sección 4a) de 17 de mayo de 2005 (RJ 2005/5720).

${ }^{29}$ No obstante, la intervención de la Administración, generalmente de carácter autonómico y local, sí ha generado un mayor grado de controversia en aquellos ámbitos en los que los poderes públicos, motivados por razones no estrictamente económicas, han mostrado su preocupación por establecer una regulación específica de la actividad profesional. Así ha sucedido con las restricciones administrativas impuestas a aquellos sectores que parecen no estar alineados con los objetivos públicos generales (tal es el caso de actividades que incidan negativamente en el ámbito de la salud o causen un impacto medioambiental negativo), así como la fijación de determinadas exigencias lingüísticas para el ejercicio del comercio [vid. STS (Sala de lo Contencioso-Administrativo, Sección $2^{\mathrm{a}}$ ) núm. 1506/2018, de 16 de octubre (RJ 2018/4637)], así como en materia de política lingüística [vid. STC núm. 88/2017, de 4 de julio (RTC 2017/88) y STC núm. 7/2018, de 25 de enero (RTC 2018/7)].
} 
normativo se fundamentará en motivos económicos y de resistencia financiera ${ }^{30}$. Asimismo, deberá tomarse en consideración, para estos casos, el carácter objetivo de la afectación, pues siempre que el legislador introduzca medidas de carácter general, éstas abarcarán a todos los agentes económicos que operen en un sector concreto del mercado y reúnan las mismas condiciones sin hacer ninguna otra diferenciación.

Un claro y reciente caso sobre este particular se ubica dentro del sector de las energías renovables. En líneas generales, la cuestión es extensamente abordada por la Sección $3^{\text {a }}$ de Sala de lo Contencioso-Administrativo del Tribunal Supremo, en su Sentencia núm. 1193/2017, de 7 de julio $^{31}$. En ella, nuestro máximo órgano jurisdiccional ordinario entra a resolver un recurso contencioso-administrativo planteado por diversas empresas energéticas del sector de la energía renovable - concretamente fotovoltaica -, por medio del cual solicitaban la declaración de nulidad de los preceptos contenidos en el Real Decreto 413/2014, de 6 de junio, así como de la Orden Ministerial que lo desarrolla (Orden IET/1344/2015, de 2 de julio), relativos a la introducción de importantes modificaciones de las instalaciones técnicas de estos centros y de los criterios de retribución de sus servicios.

En concreto, los argumentos bajo los que solicitaban la declaración de nulidad pueden reconducirse a la generación de un perjuicio económico en la medida que hacer frente a las nuevas modificaciones en sus instalaciones les suponía un coste de inversión que, además, se veía incrementado a causa de la modificación de los parámetros de retribución (menor rentabilidad). Los recurrentes alegaron la vulneración del principio de rentabilidad razonable, como fin inherente a toda actividad económica, ya que la imposición de los nuevos criterios retributivos les impedía alcanzar un nivel asequible de rentabilidad. A su vez, también manifestaron una vulneración directa a su derecho particular de libertad de empresa en la medida que, a causa de los dos gravámenes anteriores, se habían visto privados de competir en condiciones de igualdad con el resto de tecnologías energéticas.

En cuanto a la resolución del recurso, el TS pese a examinar exhaustivamente los nuevos criterios económicos y reconocer que la entrada en vigor del RD 413/2014, de 6 de junio, ha comportado una modificación sustancial de las condiciones económicas; es lo cierto que termina

\footnotetext{
${ }^{30}$ Un claro y reciente caso sobre este particular es abordado en la STS (Sala de lo Contencioso-Administrativo, Sección $3^{\circ}$ ) núm. 1193/2017, de 7 de julio (RJ 2017/3630) en referencia a la introducción de importantes modificaciones de las instalaciones técnicas y tarificación económica en el sector de las energías renovables.

${ }^{31}$ STS (Sala de lo Contencioso-Administrativo, Sección 3) núm. 1193/2017, de 7 de julio (RJ 2017/3630). Sobre el asunto referente a los cambios introducidos en el sector de la energía también se ha pronunciado el Tribunal Constitucionial en su STC núm. 270/2015, de 17 de diciembre (RTC 2015/270) en relación con la naturaleza del instrumento legislativo empleado en el caso concreto. Sin embargo, nuestro máximo intérprete constitucional no ha apreciado vulneración alguna en la medida en que no se está frente a una normativa arbitraria e individualizada, pues su ámbito objetivo de aplicación viene dado por las características particulares del sector que justifican una regulación específica sobre la materia.
} 
por desestimarlo, al no considerar que la norma legal suponga un ataque directo y discriminado a la libertad de empresa de los recurrentes. Varios son los motivos que conducen a la desestimación del recurso: en primer lugar, el TS no considera que la imposición de los nuevos criterios constituya una grave afectación de la actividad empresarial, pues los agentes económicos conservan intacta la capacidad de reintegración económica a través del ejercicio de su propia actividad (como se indica en el FJ $8^{\circ}$ de la sentencia de referencia: "las medidas adoptadas por el legislador de urgencia, aunque supongan una reducción de la retribución no impiden ni obstaculizan el ejercicio de la actividad empresarial en este sector de las energías renovables, ni ponen en riesgo las inversiones realizadas, ya que la aplicación del nuevo sistema retributivo les asegura la obtención de una rentabilidad razonable a lo largo de toda la vida útil regulatoria"; y en segundo lugar, los recurrentes incurren en una lectura errónea, hasta cierto punto paternalista, de la libertad de empresa, puesto que "desde una perspectiva material, debe significarse que la libertad de empresa no garantiza el mantenimiento de las políticas de fomento de las que puede ser beneficiario un determinado sector económico con el objeto de promover su desarrollo, que puede tener efectos distorsionantes de la actividad empresarial de otros sectores productivos vulnerando las reglas de la competencia".

De otra parte, cabe añadir que las alegaciones manifestadas por los agentes económicos respecto a posibles conculcaciones a su derecho de libertad de empresa por el hecho de que la intervención normativa no respete las garantías formales derivadas del art. 53.1 CE (reserva de ley), tampoco se han visto acompañadas de una gran tasa de éxito en sede judicial, pues nuestra jurisprudencia se ha posicionado, siguiendo su línea clásica y consolidada, por entender que, en relación con los derechos constitucionalizados carentes de carácter fundamental, la interpretación de la "reserva de ley" debe hacerse de forma extensiva, admitiendo el uso por parte del legislador de cualquier otro instrumento normativo con rango de ley formal ${ }^{32}$.

\section{DERECHO DE LA COMPETENCIA Y LIBERTAD DE EMPRESA}

Hasta lo aquí expuesto, la instauración de nuestro modelo constitucional ha supuesto el reconocimiento expreso de la libre iniciativa privada en cuanto derecho individual extensible a todo operador económico. Sin embargo, la protección individual de dicho derecho subjetivo ha pasado

\footnotetext{
32 La interpretación extensiva de la "reserva de ley formal" dispuesta en el art. 53.1 CE constituye un pronunciamiento plenamente consolidado por la jurisprudencia del TC. Respecto a este campo de estudio pueden destacarse las siguientes resoluciones: STC núm. 83/1984, de 24 de julio (RTC 1984/83); STC núm. 292/2000, de 30 de noviembre (RTC 2000/292); STC núm. 112/2006, de 5 de abril (RTC 2006/112); y más recientemente, con un extenso grado de detalle, la STC núm. 30/2016, de 18 de febrero (RTC 2016/30).
} 
muy desapercibida en los diferentes textos legales, apenas encontrando su respaldo en las instituciones generales del Derecho Civil (vgr. responsabilidad civil extracontractual, abuso de derecho, prohibición de enriquecimiento injusto).

Con todo, en los últimos años sí que es posible apreciar, como se ha tenido ocasión de evidenciar, un cierto incremento de las resoluciones judiciales que han entrado a analizar dichas relaciones horizontales, aun cuando lo hagan desde la perspectiva de solventar las consecuencias perjudiciales padecidas por sus titulares (fundamentalmente, la reparación del daño antijurídico derivado de una infracción de la competencia mediante la percepción de una indemnización pecuniaria) (PEÑA LÓPEZ, 2018, p. 161).

No debe obviarse, en cualquier caso, que la fijación de ciertas limitaciones legales pretende, en verdad, garantizar un pleno y equitativo ejercicio entre todos los derechos individuales que se interrelacionan en el tráfico económico (ALONSO SOTO, 2006, p. 273). De hecho, el derecho a la libertad de empresa es un derecho de naturaleza relacional, cuyo ejercicio comporta per se la colisión con otros derechos (GUILLÉN CARAMÉS, 2014, p. 777-778). Ello obedece a que, en un único escenario, concurren una pluralidad de operadores con el objetivo de ser los seleccionados dentro de un determinado sector económico. De esta forma, los engranajes que sostienen el proceso competitivo, junto a alentar la actividad productiva a través del "enfrentamiento tolerado" de derechos e intereses contrapuestos, también garantizan la posibilidad de desplegar esos derechos con las máximas condiciones de equidad, pues todos los operadores contarán con el mismo respaldo y protección normativa con el que hacer frente al éxito de su elección y conforme a sus propis méritos, capacidades y recursos ${ }^{33}$.

Sin embargo, la libertad de empresa no debe interpretarse como la concesión de una especie de "carta blanca" a favor de los agentes económicos para que éstos hagan prevalecer su posición en detrimento de aquella otra que corresponde al resto de operadores económicos. Es necesario definir los límites al ejercicio de las diferentes libertades empresariales que pueden coexistir en un mismo mercado. Por ello resulta conveniente, en este punto, proceder a delimitar aquellos comportamientos que, pese a causar ciertos perjuicios a los competidores, quedan resguardados bajo el manto protector del art. $38 \mathrm{CE}$ y, en consecuencia, deben ser asumidos y tolerados por el proceso competitivo; así como aquellos otros que, por el contrario, sí son merecedores de

\footnotetext{
${ }^{33} \mathrm{El}$ ánimo de rivalidad, propio del proceso competitivo, se encuentra reflejado especialmente en la Ley 3/1991, de 10 de enero, de Competencia Desleal, pues ésta se encarga de fijar toda una serie de conductas prohibidas por atentar contra la buena fe empresarial. Podría decirse, pues, que el legislador ofrece un respaldo a la confrontación económica en la medida en que se ocupa de prohibir los excesos propios de ésta, protegiendo así, por extensión, tanto al resto de operadores económicos, como a los usuarios y consumidores (vid. BROSETA PONT, Manuel. Manual de Derecho Mercantil, $15^{a}$ ed. Madrid: Tecnos, 2018, 1 v., págs. 165-166; JIMÉNEZ CARDONA, Noemí. Acciones por daños derivados de las infracciones del Derecho de la Competencia: aspectos sustantivos y procesales. Madrid: Bosch Wolters Kluwer, 2021, págs. 15-19; MENÉNDEZ MENÉNDEZ, Aurelio. Constitución, sistema económico y Derecho mercantil. Madrid: Cantoblanco, 1982, págs. 57-59).
} 
persecución por parte de las autoridades competentes, por cuanto el operador, en la búsqueda exclusiva de su interés privado, se excede en el ejercicio legítimo de su actuación empresarial y, por ende, causa un perjuicio que, en modo alguno, es admitido por nuestro sistema económicoconstitucional (NIVARRA, 1997, p. 1449-1461).

Debe tenerse presente que las conductas que conculcan el libre juego de la competencia, o bien impliquen un falseamiento de la misma, presuponen, a su vez, la previa existencia de un ejercicio exorbitado de la libertad de empresa (GHIDINI, 1978, p. 68-69). Las manifestaciones abusivas de dicha libertad, cometidas por un operador económico, podrán ser perseguibles, con carácter general, a través de los cauces previstos en materia de defensa de la competencia y competencia desleal (WAELBROECK y FRIGNANI, 1998, p. 265-266). Ello es relevante si se contrasta con el hecho de que nuestro sistema constitucional no ha establecido un cauce específico de protección al que puedan acudir el resto de titulares que tuviesen afectados sus derechos individuales (negación de la eficacia horizontal del art. $38 \mathrm{CE}$ entre particulares) ${ }^{34}$.

Un ejemplo de candente actualidad, que además repercute en la libertad de elección y movilidad de los consumidores, es el referente a la problemática que acompaña al sector de servicios de intermediación de transporte (más conocido como la "guerra del taxi”), cuya cuestión de fondo no es otra que definir los límites al ejercicio de las libertades empresariales que se desarrollan entre los diferentes segmentos de un mismo mercado y que aparecen, dadas las características de su ámbito de actividad (alta regulación administrativa vs. reglas del libre mercado), envueltas en una intensa confrontación. A pesar de las circunstancias, todo parece indicar que la colusión de derechos entre operadores de servicios de transporte deberá resolverse en la contienda (TARRÉS VIVES, 2019, p.9-10).

Nuevamente, corresponderá a los órganos jurisdiccionales ofrecer respuesta a las peticiones suscitadas tanto por parte de los titulares de autorizaciones VTC, como de los empresarios del taxi. Respecto de los primeros, les competerá la labor quirúrgica de determinar el contenido esencial del derecho de libertad de empresa que es desplegado en su activad, así como dirimir acerca de la proporcionalidad de aquellas limitaciones introducidas por la actividad normativa de los poderes

\footnotetext{
${ }^{34}$ La STS (Sala de lo Civil, Sección $1^{\text {a }}$ ) núm. 1136/2007, de 25 de octubre (RJ 2007/8638) se pronuncia expresamente en torno a una posible conculcación horizontal del derecho a la libertad de empresa que tiene lugar entre operadores económicos. En este sentido, pese a no negar la existencia acerca de la causación de un posible perjuicio, lo cierto es que el Alto Tribunal no se pronuncia sobre el fondo de la cuestión, pues advierte que ésta no es la vía procesal establecida por nuestro ordenamiento jurídico: "el derecho a la libertad de empresa (y con independencia de su valor como ingrediente de otro derecho fundamental, o fundamento de normativa de legalidad ordinaria), no tiene, en la perspectiva que se examina, de garantía constitucional, eficacia horizontal o entre particulares, la que suele expresarse con la expresión alemana Drittwirkung, que en sentido literal significa "eficacia frente a terceros". Y como en el caso lo que se pretende es que la Agrupación de Radio-Taxi de Tarragona, un sujeto particular, adoptó un acuerdo que infringe el derecho constitucional a la libertad de empresa del art. 38 CE, es obvio que el planteamiento debe ser desestimado por no ser adecuada la garantía o tutela invocada para fundamentar la pretensión de nulidad ejercitada”.
} 
públicos. En cuanto a los segundos, la cuestión de fondo versará sobre el marco normativo actual y si éste realmente les conduce a una situación de desventaja competitiva al impedirles concurrir en similares condiciones que el resto de operadores o, por el contrario, resulta ser una contingencia inherente al desempeño de la actividad profesional, cuyas consecuencias quedan subsumidas dentro del riesgo empresarial propiciado por el avance natural de los mecanismos de libre mercado.

Hasta el momento, son varias las resoluciones judiciales que han desestimado las pretensiones del sector del taxi en cuanto a considerar, como prácticas de competencia desleal, la actividad empresarial desempeñada por las compañías VTC. En esta línea de posicionamiento, vid. la SAP de Madrid (Sección 28ª) núm. 14/2019, de 18 de enero (JUR 2019/70150) que confirma el pronunciamiento emitido por el Juzgado de lo Mercantil núm. 12 de Madrid en su Sentencia núm. 159/2017, de 13 de junio (JUR 2017/163178). Más recientemente, el TS ya ha tenido la primera ocasión de pronunciarse acerca de la proporcionalidad de las restricciones introducidas para las autorizaciones VTC. En concreto, ha correspondido a la Sección $3^{\text {a }}$ de la Sala de lo ContenciosoAdministrativo en su Sentencia núm. 921/2018, de 4 de junio (RJ 1913/2017) con la que, entrando a resolver el recurso contencioso-administrativo interpuesto por la CNMC por el que impugnaban las limitaciones, tanto cuantitativas como cualitativas, de las autorizaciones VTC, la Sala finalmente confiere plena validez a sus restricciones -con exclusión, eso sí, de la exigencia relativa al número mínimo de siete vehículos para el ejercicio de la actividad- al considerar que "los poderes públicos pueden optar entre el modelo vigente de asegurar un servicio de taxi con dichas características (en cuyo caso tal opción puede admitirse como una razón imperiosa de interés general) o bien dejar el transporte urbano sometido exclusivamente a la libre competencia: la opción escogida constituye una decisión de política sobre el transporte urbano cuyo límite está configurado por la necesidad, proporcionalidad y carácter no discriminatorio de las medidas regulatorias impuestas "..

Un tema éste, relativo a la guerra del taxi, sobre el que todavía queda mucho por escribir y que, en este primer trimestre de 2021, ha vuelto a plantearse, por ejemplo en Barcelona, con la "reaparición”, aun cuando en condiciones especiales, del servicio de Uber y, por ende, la activación de las movilizaciones de diferentes sectores sindicales del sector del taxi.

\section{CONCLUSIONES}

Garantizar un pleno ejercicio de la libertad empresarial solo puede alcanzarse en un espacio de plena y real competencia económica. Ésta, por su parte, solo puede ser el resultado de un perfecto equilibrio de fuerzas en el mercado, en el bien entendido que éste solo puede tener lugar si cada grupo que interviene en el intercambio económico (demanda y oferta) queda cubierto por una

especie de "tensión natural" que les conduce a disputarse, de una parte, la supervivencia (en 
términos de rentabilidad económica); y, de otra, la máxima satisfacción (en términos de costeadquisición). En la mayoría de los ordenamientos jurídicos actuales, el criterio cuantitativo de la competencia (exigencia de concurrencia) se ha visto reemplazado por un nuevo criterio cualitativo (ánimo de rivalidad), lo cual les ha permitido tomar conciencia acerca de la inexistencia de una "competencia perfecta" sustentada en la capacidad de auto-regulación del propio mercado.

Sin embargo, la competencia económica, como auténtico presupuesto de la propia existencia del libre mercado, no está exenta de sufrir "comportamientos patológicos". Ello es así, porque la capacidad auto-normativa del mercado para hacer frente a sus "anomalías de funcionamiento" no solo es insuficiente (vgr. cuando el poder de negociación que tiene la demanda dentro del mercado relevante es insignificante, o bien cuando el acto atentatorio proviene de un agente dominante); sino que también, en ciertos casos, puede llegar a estar viciada (por ejemplo, en aquellas situaciones donde existe un claro ánimo de concertación entre varios agentes económicos que, definitivamente, culmina con la creación de cárteles).

El mercado, per se, con todos sus elementos y actores, aun cuando puede dirigir la correcta senda de desarrollo de la actividad empresarial, es lo cierto que carece de mecanismos de "autotutela" que permitan corregir y reprimir aquellas actuaciones propias de sus operadores que, con el único objetivo de alcanzar resultados favorables para sus particulares intereses, terminan por constituir no solo una vulneración del sistema económico, sino también un atentado contra el resto de intereses públicos y sociales que en él también se desarrollan. De ahí, precisamente, la necesidad de un mandato de intervención pública, guiado por el análisis vertical del art. $38 \mathrm{CE}$, que deriva en la creación y consolidación del Derecho de la Competencia.

El núcleo fundamental de nuestro modelo económico se sustenta en el reconocimiento en el art. $38 \mathrm{CE}$ de la libertad de empresa en el marco de una economía de mercado. Una libertad de empresa que ostenta una naturaleza dual, pues si bien es verdad que se erige, institucionalmente, en un principio inspirador de nuestro sistema económico, no lo es menos que también adquiere notable repercusión, en cuanto derecho subjetivo de carácter socioeconómico y de desarrollo continuo, en orden a todos y cada uno de los protagonistas que participan en el propio mercado.

La complejidad propia del ejercicio de este derecho subjetivo, motivada en gran parte por la inconcreción de nuestro legislador, así como por la obligada naturaleza relacional que presenta este derecho entre la pluralidad de sujetos que operan en el mercado, ha conducido a innumerables situaciones de conflicto. La mayor parte de ellas, como así es apreciable respecto a la regulación del sector de las energías renovables o en orden a la incipiente revolución tecnológica que ocupa al sector del transporte de personas, pueden reconducirse a situaciones de restricción de las facultades empresariales que tienen su razón de ser en la intervención normativa de las autoridades públicas, 
o bien venir referidas a situaciones de colisión o confrontación de derechos y libertades empresariales entre operadores económicos de carácter privado.

La respuesta a todos estos inconvenientes suele ser el resultado de la contienda judicial. Los pronunciamientos de los órganos jurisdiccionales españoles sobre el correcto ejercicio del derecho de libertad empresarial exigen que éste deba ser interpretado de conformidad con el contexto social en que se desenvuelve, pero siempre teniendo en cuenta que no es un derecho absoluto, sino sometido, en función del riesgo regulatorio, a lícitos límites y restricciones. En todo caso, se advierte como la jurisprudencia no ofrece un posicionamiento unánime ni homogéneo sobre la materia objeto de este análisis, sino que, con acierto, nos sitúa ante la necesidad de atender a estrictas razones de interés público, así como hacerlo de acuerdo con los principios de proporcionalidad, idoneidad y mínima afectación que concurra en cada caso concreto.

\section{V. ÍNDICE BIBLIOGRÁFICO}

AJA FERNÁNDEZ, Eliseo. Inmigración y democracia. Madrid: Alianza, 2012.

ALONSO SOTO, Ricardo. Derecho de la competencia. Introducción y Derecho Comunitario. En Aurelio Menéndez y Rodrigo Uría (Dirs.) Curso de Derecho Mercantil. Madrid: Civitas, 2006, 1v.

ÁLVAREZ CONDE, Enrique y TUR AUSINA, Rosario. Derecho Constitucional. Madrid: Tecnos, 2016.

AREEDA, Phillip. Introduction to antitrust economics. En Eleanor Fox y James Halverson (Dirs.) Antitrust policy in transition: the convergence of law and economics. Washington: American Bar Association, 1984.

ARIÑO ORTIZ, Gaspar. "La iniciativa pública en la Constitución. Delimitación del sector público y control de su expansión”. Revista de Administración Pública, Madrid, 1979, núm. 1, pág. 55-106.

BACHES OPI, Sergio. La jurisprudencia del Tribunal Supremo en materia de Derecho de Defensa de la Competencia desde la entrada en vigor de la Ley 15/2007. En Baches Opi (Dir.) La Ley 15/2007 de Defensa de la Competencia: balance de su aplicación. Madrid: Ley-Wolters Kluwer, 2010.

BARRE, Raymond. Economía política, 5ª ed. Barcelona: Ariel, 1967, 1v.

BASSOLS COMA, Martín. Constitución y sistema económico. Madrid: Tecnos, 1985.

BROSETA PONT, Manuel. Manual de Derecho Mercantil, 15ª ed. Madrid: Tecnos, 2018, 1v.

CAZORLA PRIETO, Luís María. Comentario al artículo 38. En Garrido Falla (Dir.) Comentarios a la Constitución. Madrid: Civitas, 1980.

DÍEZ-PICAZO, Luís María. Sistema de derechos fundamentales. Madrid: Civitas, 2013. 
FIKENTSCHER, Wolfgang. "Las tres funciones del control de la economía (Derecho antimonopolio)". Revista de Derecho Mercantil, Madrid, 1984, núm. 172-173, pág. 459-486.

FONT GALÁN, Juan Ignacio. Constitución económica y Derecho de la Competencia. Madrid: Tecnos, 1987.

GALÁN CORONA, Eduardo. "La empresa como destinataria de las normas de defensa de la competencia”. Actas de Derecho Industrial, Madrid, 1975, núm. II, pág. 291-346.

GHIDINI, Gustavo. Slealtà della concorrenza. Bologna: CEDAM, 1978.

GOIG MARTÍNEZ, Juan Manuel. Comentarios a la Constitución Española de 1978. En Alzaga Villaamil (Coord.) Comentarios a la Constitución Española de 1978, Madrid: EDERSA Cortes Generales, 1996, III v.

GUILLÉN CARAMÉS, Javier. La descentralización del Derecho de la Competencia en España. En García Cruces (Coord.) Tratado de Derecho de la Competencia. Valencia: Tirant lo Blanch, 2014, $1 \mathrm{v}$.

HERNÁNDEZ DELGADO, José. La actividad reguladora del Estado y la competencia. En Ortiz Blanco (Dir.) Derecho de la competencia europeo y español: curso de iniciación. Madrid: Dykinson, 1999.

HERRERO SUÁREZ, Carmen. Los contratos vinculados (tying agreements) en el Derecho de la Competencia. Madrid: La Ley-Wolters Kluwer, 2006.

JIMÉNEZ CARDONA, Noemí. Algunas reflexiones procesales acerca de los contratos de distribución. En Liber Amicorum del Prof. Francisco Ramos Méndez. Barcelona: Atelier, 2018, 2 $\mathrm{v}$.

JIMÉNEZ CARDONA, Noemí. La dimensión constitucional del Derecho de la Competencia. Curitiba: Juruá Editora, 2021.

JIMÉNEZ CARDONA, Noemí. La aplicación del Derecho Antitrust en los EEUU. Juruá Editora, 2021.

JIMÉNEZ CARDONA, Noemí. Acciones por daños derivados de las infracciones del Derecho de la Competencia: aspectos sustantivos y procesales. Madrid: Bosch Wolters Kluwer, 2021.

MARCOS FERNÁNDEZ, Francisco. “PPuede sancionarse a las Administraciones Públicas cuando no actúan como operador económico si restringen la competencia o promueven conductas anticompetitivas?". InDret: Revista para el análisis del Derecho, Barcelona, 2018, núm. 1, pág. 141.

MARTÍNEZ VAL, José María. Artículo 38: Libertad de empresa. En Alzaga Villaamil (Coord.) Comentarios a las Leyes Políticas. Madrid: Editorial de Derecho Público, 1983, 3v.

MENÉNDEZ MENÉNDEZ, Aurelio. Constitución, sistema económico y Derecho mercantil. Madrid: Cantoblanco, 1982.

MONEDERO GIL, José Ignacio. "La estructura de la empresa pública en España”. Revista de Administración Pública, Madrid, 1982, núm. 99, pág. 7-36. 
MORALES BARCELÓ, Judith. "Las plataformas digitales y la economía colaborativa: especial referencia a la facilitación del intercambio de información". Revista Aranzadi de derecho y nuevas tecnologías, Madrid, 2020, núm. 53, pág. 1 y ss.

NAVAS LÓPEZ, José Emilio y GUERRAS MARTÍN, Luís Ángel. Fundamentos de dirección estratégica de la empresa. $2^{\mathrm{a}}$ ed. Navarra: Thomson Reuters, 2016.

NIVARRA, Luca. La tutela civile: profili sostanziali. En Aldo Frignani (Dir.) Diritto antitrust italiano. Bologna: Zanichelli Editore, 1997, 2v.

OROMÍ VALL-LLOVERA, Susana. "El ejercicio de acciones de responsabilidad por los perjudicados en materia de derecho de la competencia". Revista vasca de derecho procesal y arbitraje, Guipúzcoa, 2016, vol. 28, núm. 1, pág. 101-115.

ORTIZ BLANCO, Luís (Dir.). Manual de Derecho de la Competencia, Madrid: Tecnos, 2008.

ORTIZ-ARCE, Antonio. "El principio de igualdad en Derecho económico". Revista Española de Derecho Constitucional, Madrid, 1984, año 4, núm. 11, pág. 107-120.

PAZ-ARES RODRÍGUEZ, José Cándido y ALFARO ÁGUILA-REAL, Jesús. Comentarios a la Constitución Española. En Casas Baamonde y Rodríguez Piñero (Dirs.). Comentarios a la Constitución Española. Madrid: Wolters Kluwer, 2008, 1v.

PEÑA LÓPEZ, Fernando. La responsabilidad por daños a la libre competencia. Valencia: Tirant lo Blanch, 2018.

ROJO FERNÁNDEZ-RÍO, Ángel José. “Actualidad económica pública y actividad económica privada en la Constitución española". Revista de Derecho Mercantil, Madrid, 1983, núm. 169-170, pág. 309-344.

SAMUELSON, Paul y NORDHAUS, William. Economía. 13ª ed. Madrid: McGraw-Hill, 1991.

SAINZ MORENO, Fernando. "El principio de libre competencia como manifestación del orden público económico". Revista española de Derecho Administrativo, Madrid, 1980, núm. 24, pág. 134-138.

SPULBER, Daniel. Unlocking technology: antitrust and innovation. En Geofrey Manne y Joshua Wright (Dirs.). Competition policy and patent law under uncertainty. New York: Cambridge University Press, 2013.

TARRÉS VIVES, Marc. "Economía colaborativa e innovación tecnológica en el transporte urbano de viajeros en automóviles de turismo". IDP: Revista de Internet, Derecho y Política, Barcelona, 2019, núm. 28, págs. 1-20.

VALLESPÍN PÉREZ, David. El régimen profesional de los trabajadores autónomos y sus especialidades. Barcelona: Bosch, 2018.

VALLESPÍN PÉREZ, David. Litigios de consumo: especialidades procesales y acciones colectivas. Barcelona: Bosch, 2018.

VÁZQUEZ ALBERT, Daniel. El contrato de distribución exclusiva. En Ruiz Peris (Dir.) Contratos de distribución: agencia, distribución, concesión, franquicia, suministro y estimatorio. Barcelona: Atelier, 2018. 
VICIANO PASTOR, Pablo. Intervención pública en la economía y libre competencia. En García Cruces (Coord.). Tratado de Derecho de la Competencia. Valencia: Tirant lo Blanch, 2014, 1v.

WAELBROECK, Michel y FRIGNANI, Aldo. Derecho europeo de la competencia. Barcelona: Bosch, 1998, 1v.

Trabalho recebido em 31 de outubro de 2021 Aceito em 31 de outubro de 2021 